\title{
Influence of chemical composition of the dental paste on the buffering systems in the mouth and the environmental indicator
}

\author{
(C) Svetlana N. Gromova, ${ }^{1}{ }^{*}$ Svetlana A. Kuklina, ${ }^{2}$ Anton V. Elikov, ${ }^{2}$ \\ Olga A. Smetanina, ${ }^{1}$ and Sergey B. Petrov ${ }^{3}$ \\ ${ }^{1}$ Department of Dentistry. ${ }^{2}$ Department of Chemistry. ${ }^{3}$ Department of Hygiene. Federal State Budgetary \\ Educational Institution of Higher Education "Kirov State Medical University" of the Ministry of Healthcare \\ of the Russian Federation. K. Marx St., 112. Kirov, 610998. Kirov Region. Russia. \\ Phone:+7 (8332)64-09-76.E-mail:med@kirovgma.ru
}

*Supervising author; ${ }^{+}$Corresponding author

Keywords: buffer systems of saliva, the acid-base balance in the oral cavity, enamel demineralization, toothpaste composition.

\section{Abstract}

In this paper we consider buffering properties of saliva, which are regulated by a colloidal system. It includes $\mathrm{Ca}^{2+}$ and $\mathrm{HPO}_{4}{ }^{2-}$ ions, which affect on qualitative characteristics of saliva. The constancy of the $\mathrm{pH}$ determines neutralizing and mineralizing capabilities of saliva. The aim of this work was to define influence of toothpaste composition on the $\mathrm{pH}$, salivary buffer systems, and the acid-base balance in the oral cavity. The acid-base disruption results in disbalance in demineralization-remineralization processes. Students of the Dentistry Department of Kirov State Medical University of the Ministry of Health of Russia took part in this research. They were divided into three groups. Each group had been using different products for 28 days. We selected 3 toothpastes of the same manufacturer. These toothpastes contain same ingredients, which by their chemical properties are not able to affect on the $\mathrm{pH}$ of the oral fluid and salivary buffer systems accordingly. However, there were distinctive components such as dicalcium phosphate dihydrate, hydroxyapatite, tetrakali pyrophosphate, calcium lactate, which increase $\mathrm{NRA}^{2-}$ and $\mathrm{Ca}^{2+}$. This fact has a positive effect on maintaining fixity of the phosphate buffer system in the oral cavity. It therefore helps to normalize the $\mathrm{pH}$ to a neutral level. The acid-base equilibrium is supported by buffering properties of saliva. It knows that saliva is regulated by the colloidal system including $\mathrm{Ca}^{2+}$ and $\mathrm{HPO}_{4}{ }^{2-}$ ions. These ions are part of the phosphate buffer system, which affect on qualitative characteristics of saliva. Based on the above, there is dependence between the row of toothpaste ingredients and protein level, hydrogen phosphate ions, calcium ions, and $\mathrm{pH}$ values.

\section{References}

[1] S.N. Gromova, A.M. Khamadeeva, A.V. Sinitsyna, T.A. Gavrilova. Dental morbidity of school-age children in Kirov region. Pediatric Dentistry and Prevention. 2016. No.1. P.72-77. (russian)

[2] S.N. Gromova, A.V. Sinitsyna. Intensity and prevalence of signs of periodontal diseases among the adult population in Kirov and Kirov region. Materials of the XVIIIth All-Russian scientific conference among students and young scientists with international participation "Youth and Medical Science in the XXIth Century" Kirov-April 12-14, 2017. P.295-296. (russian)

[3] G.R. Badretdinova. The acid-base balance in the oral cavity and ionized calcium of mixed saliva during complicated caries of children [Text] (Author: PhD Thesis for medical sciences). Moscow. 1994. 24p. (russian)

[4] O.A. Smetanina, L.N. Kazarina, A.S. Gordetsov, O.V. Krasnikova. Infrared spectroscopy of the oral fluid as a method for early diagnosis of inflammatory periodontal diseases in children [Electronic resource]. Modern problems of science and education. 2016. No.6. URL: http://www.scienceeducation.ru/article/view?id=25848 - Date of access: 05.04.18. (russian)

[5] O.A. Smetanina. Prevention and diagnosis of gingivitis using infrared spectroscopy method of biological oral fluids: PhD Thesis for medical science: 01.14.14. Smetanina Olga Anatolevna; [A protection Place: Med.akad. them. S.I. St. George], 2018. 149p. (russian)

[6] C.B. Ulitovsky. Toothpastes (review). New in dentistry. 1999. No.7. P.12 -20. (russian)

[7] V.A. Rumyantsev, M.A. Dubova, L.K. Yesayan, E.V. Bityukova, S.N. Gromova. Typical forms of the acid-base balance in the oral cavity. The XIIth International Conference of oral and maxillofacial 
INFLUENCE OF CHEMICAL COMPOSITION OF THE DENTAL PASTE ON THE BUFFERING SYSTEMS... 104-110 surgeons and dentists "New Technologies in Dentistry" (Conference proceedings). St.Petersburg. May 22-24, 2007. P.184-185. 243p.

[8] B.N. Davidov, O.A. Gavrilova, V.A. Rumyantsev, I.M. Teperina. Oral acid-base balance in children with congenital cleft upper lip and palate. J.P.F.A. 2000. Vol.14. No.2. P.45-51.

[9] I.V. Namestnikova, V.A. Rumyantsev, G.N. Podgorny, G.V. Dekutovich. Changes in the level of calcium, inorganic phosphate, the ratio of calcium/phosphate and the $\mathrm{pH}$ in mixed saliva under influence of using "Orbit" gum. Actual problems of scientific and pedagogical dentistry: materials of the anniversary scientific and methodological conference dedicated to the 100th birthday of Professor T. T. Schoolboy; under the editorship of prof. V.A. Rumyantseva and A.Zh. Petrikas. [Text]. Tver: LLC Triad Publishing House. 2005. 152p. P.43-44.

[10] Y. Lijima, F. Cai, P. Shen, G. Walker, C. Reynolds, E.C. Reynolds. Acid resistance of enamel subsurface lesions remineralized by a sugar-free chewing gum containing casein phosphopeptideamorphous calcium phosphate. Caries Res. 2004. Vol.38. P.551-556.

[11] O.A. Gavrilova, V.A. Rumyantsev. The focus of compensatory reactions in the system of regulation of the acid-base balance in the oral cavity, V: "Epidemiology, prevention and treatment of major dental diseases in children" (Materials of the scientific and practical conference dedicated to the 30th anniversary of the Department of Pediatric Dentistry TSMA), ed. prof. B.N. Davydova. Tver, RIC TGMA. 2004. 300p. P.38-40. (russian)

[12] V.A. Rumyantsev, V.V. Belyaev, V.A. Zubtsov, E.A. Kolobaev, M.S. Andrusenko, I.V. Namestnikova. The effect of using a gum with sweeteners on the acid-base balance in the oral cavity: a double-blind study. Verkhnevolzhsky Medical Journal. 2010. Vol.8. No.3. P.24-26. (russian)

[13] K.V. Sokolova, A.V. Voinova, A.V. Elikov, P.I. Tsapok. The influence of diabetogenic factors on the biochemical parameters of mixed saliva. Medical education today. 2018. No.3(3). P.14-26. (russian)

[14] E.V. Borovsky, V.K. Leontiev. Biology of the oral cavity. Moscow: Medicine. 1991. 301p. Bibliography: P.86-196. (russian)

[15] S.N. Gromova. Regulation of the microbial, acid-base and mineral balance in the oral cavity using modern hygiene products. Dissertation for the degree of candidate of medical sciences. GOUVPO "Tver State Medical Academy". Tver. 2011. P.82. (russian) 